\title{
The ruins of the immaterial
}

\author{
Jonathan Hill
}

\section{Building books}

The architect as we understand the term today was established in Italy in around 1450, in France a century later and in Britain in the early 1600s. The command of drawing - not building - unlocked the status of the architect. The term "design" derives from the Italian disegno, which associates the drawing of a line with the drawing forth of an idea. Disegno allowed the three visual arts - architecture, painting and sculpture - to be recognised as liberal arts concerned with individual, intellectual labour, a status they had rarely been accorded previously. In the new division of labour, architects acquired complementary means to practice architecture that were as important as building, namely drawing and writing, creating an interdependent and multi-directional web of influences that together stimulated architects' creative development. To affirm their newly acquired status, architects began increasingly to theorise architecture both for themselves and for their patrons, ensuring that the authored book became more valuable to architects than to painters and sculptors, whose status was more secure and means to acquire commissions less demanding. In contrast to the architectural drawing, which is seen in relation to other drawings and a building, the painting is unique and need not refer to an external object, thus appearing further removed from the material world and closer to that of ideas.

Written in around 1450 and published in 1485, Leon Battista Alberti's De re aedificatoria (On the Art of Building in Ten Books) was the first thorough investigation of the Renaissance architect as artist and intellectual. Francesco Colonna's Hypteromachia Poliphili (1499), was the second architectural book by a living writer published in the Renaissance and the first to be printed with illustrations, establishing the multimedia interdependence of text and image that has been essential to architectural books ever since. One model for the architectural book, Hypnerotomachia Poliphili is a fictional narrative illustrated with pictorial representations in which love is lost and among monuments and ruins in a sylvan landscape. A second model is the analytical manifesto justified through principles and examples and illustrated with orthogonal drawings, such as Andrea Palladio's I quattro libri dell' archittetura (The Four Books of Architecture, 1570). The relationship between history and design was central to both authors, although they did not aim to be rigorous and objective in the manner of later historians. Historical references appear in both books but for different purposes. In one they enrich a specific story, in the other they legitimise generic architectural solutions. A further literary model, the manual conveys practical knowledge and is illustrated with diagrams and calculations. But these models are not hermetic and many architectural books refer to more than one, as is the case in Palladio's attention to practical matters in The Four Books.

\section{Things of a natural kind}

Classical antiquity associated the material with temporal decay and the immaterial with timeless, geometric order. Consequently, in the Renaissance, disegno emphasised the immaterial idea of architecture not the material fabric of building, and the architectural imagination was restricted to the universal, unchanging geometries of ideal forms. But in built architecture, the relations between the immaterial and the material were sometimes considered with great subtlety. Modesty scaled farms in most cases, Palladio's villas recall the relaxed rural life 
evoked in classical antiquity by Virgil and Pliny the Younger, while their elegant but inexact proportions refer to the immaterial and its uncertain presence in the physical world. Emphasising this distinction, the buildings drawn in The Four Books of Architecture are each an ideal, not those actually built. Subsequently, the baroque drew further attention to subjective interpretation; for example, baroque drama exploited the dialectical potential of allegory, in which meanings are not fixed but endlessly changing and open to appropriation and revision. In a more significant departure, John Locke dismissed the search for ultimate truth in $A n$ Essay Concerning Human Understanding (1690), emphasising that ideas are subject to experience and provisional rather than universal. Accepting that there are limits to what we can know, Locke argued that conclusions must be in proportion to the evidence: "Our business here is not to know all things, but those which concern our conduct."1 The Enlightenment - the natural light of reason - assumed that nature and humanity are subject to the same divine laws and available for rational investigation. The principal British contribution to Enlightenment theory was empiricism, which promoted reason but made it specific rather than generic. Offering an evocative metaphor, Locke stated that the mind begins as a "white Paper”, an empty cabinet, which experience furnishes with understanding, and he distinguished between the simple ideas of sensations, over which the mind has no control, and complex ideas, which the mind creates by selecting and combining simple ideas. ${ }^{2}$ But, acknowledging the observer's role in shaping experience, later empiricists came to recognise that empirical investigation without prior concepts is impossible, concluding that personality and morality develop through an evolving dialogue between the environment, senses and mind.

Emphasising moderation and restraint, Locke required a degree of detachment from the natural world, while Anthony Ashley Cooper, third Earl of Shaftesbury, influenced a further reassessment. Previously, uncultivated nature was considered to be brutish and deformed because the immaterial soul, "as a visitor in matter", could not "be truly at home in nature", remarks Ernest Tuveson. ${ }^{3}$ Recuperation in nature found enhanced expression in the early eighteenth century, when nature and moral virtue were linked for the first time. Shaftesbury confirmed Locke's appreciation of liberty and reason but tempered his empiricism and egalitarianism. Unlike his tutor, the pupil acknowledged an ideal order, reasserting the humanist tradition of Renaissance Italy and its respect for the "immutable truths" of classical antiquity: "Twas Mr. Locke that struck at all Fundamentals, threw all Order and Virtue out of the World". ${ }^{4}$ However, departing from Plato, Shaftesbury conceived nature not as debased but as a means to contemplate the divine. ${ }^{5}$ Sensitivity to one's environment became as necessary as sensitivity to others. In the second volume of Characteristicks of Men, Manner, Opinions, Times (1711), Shaftesbury praises nature and weather: "enliven'd by the Sun, and temper'd by the fresh AIR of fanning Breezes! ... I shall no longer resist the Passion growing in me for Things of a natural kind." 6

\section{Cultivating landscapes}

Locke 1975: bk. 1, ch. 1, 46.

Locke 1975: bk. 2, ch. 1, 104.

Tuveson 1960: 11.

Shaftesbury 1900: 403

Plato 1929: 121.

Shaftesbury 1999: vol. 2, 94-101.

Darwin 1996: 109.
Derived from the Latin nascere, meaning "to be born", the term "nature" has numerous meanings in which the principal distinction is between, first, a concept through which humans define themselves in relation to what they think they are not, and, second, the phenomena and processes of which humans are a part, as in, for example, Charles Darwin's theory of evolution in The Origin of Species (1859). ${ }^{7}$

The term "landscape" initially referred to land managed and cultivated by an agrarian community. Expanding its meaning, by the sixteenth century it also 
referred to a picture of nature and in the eighteenth century it was applied to a prospect of actual nature, which in 1770 Thomas Whately so vehemently stated was "as superior" to a mere "painting, as a reality to a representation". 8 In each of these meanings, "landscape" acknowledges a human intervention, indicating why the prefix "natural" is applied to a landscape that is seemingly unaffected by humanity even though this has been impossible for centuries. Such a landscape is culturally defined, reflecting what we have learned to see as natural, notably so in Britain, the first industrialised nation.

The earliest meaning of the term "culture" also referred to farmland, which endured from the Middle Ages to the late eighteenth century. A further meaning originated in the early sixteenth century and emphasised that the successful and prosperous cultivation of land enabled a person to become cultivated and cultured. Both meanings were in use in the eighteenth century, but only the second - human culture - continued into the nineteenth century. Jonathan Bate describes the picturesque landscape as "a symptom of the growing division between" the two "senses of the word "culture". ${ }^{9}$ But as it was conceived holistically in social, aesthetic and ecological terms, the eighteenth-century estate can, alternatively, be understood as a key moment when nature and culture were interdependent in meanings of the term "landscape".

\section{Landscapes of architecture}

In Britain, the architect associated with disegno was in its infancy when another appeared alongside it, focusing first on gardens not buildings because they were more clearly subject to the changing natural world. The new reverence for subjectivity and nature, and the association of one with the other, found expression in the picturesque, which is a deceptive term because it emphasises one aspect of the eighteenth-century garden to the detriment of its other qualities, such as the importance of the senses and the seasons to design, experience, understanding and the imagination. An emphasis on pictorial composition may profess a love of nature that forces nature to imitate art, making landscapes appear natural and implying that certain social relations and environmental transformations are natural too. But to dismiss the pictorial aspect of landscape as merely a prospect on property, as some critics have done, is to deny the complex painting history that informed the picturesque and also to ignore the subtlety of garden designs and drawings.

In a letter to Pope Leo X, c. 1519, Raphael associated the picture with the painter and the plan with the architect. ${ }^{10}$ But the value given to experience in the eighteenth century made this distinction less convincing. William Kent continued to depict his building designs in orthogonal drawings, but his garden designs - and often his garden buildings too - were presented pictorially. Employing multiple perspectives in a single image, and conceiving a network of inter-related scenes and alternative routes, Kent designed in response to specific natural settings and incorporated varied themes in a single garden, such as history, politics, love and death.

Accommodating multiple journeys, abundant allegories and imported trees, the picturesque was associated with the choices and opportunities available to the fortunate and prosperous in eighteenth-century English society, and came to personify the liberty and liberalism they professed. Focused on the fleeting pleasures of the present, an increasingly secular age emphasised the seasons of a life as well as the seasons of a year, and encouraged a new type of design and a new way of designing, which valued the ideas and emotions evoked through experience. The picturesque adopted the ruin as its emblem, a hybrid of architecture

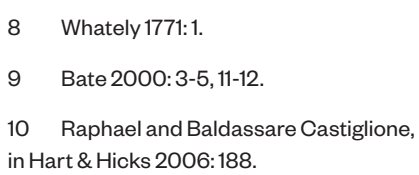

8 Whately 1771: 1.

10 Raphael and Baldassare Castiglione, in Hart \& Hicks 2006: 188. 
and landscape, nature and culture, which was understood to represent growth as well as decay, potential as well as loss, the future as well as the past. Rather than a finite object, the ruin acknowledged the effects of time and place, emphasising a symbiotic relationship with its ever-changing immediate and wider contexts that recognised the creative influence of natural as well cultural forces. Rather than timeless and distinct from the material, the eighteenth century increasingly conceived the immaterial as temporal and subject to experience, not only in the actual absence of matter but also in the perceived absence of matter seen through mists and storms, establishing a dialogue between the immaterial and material that associated self-understanding with the experience of objects subject to weathering and decay. Diminishing an object physically, ruination was understood to expand its metaphorical potential: "for imperfection and obscurity are their properties; and to carry the imagination to something greater than is seen, their effect", concluded Whately. ${ }^{11}$ Britain was so associated with its landscape that the ruin offered a means to negotiate between nature and culture. Evoking life and death in a single object, the ruin of a building was linked to the ruin of person or a place, as well as their potential for renewal. For an individual and for an island nation, self-understanding was synonymous with the experience of landscape in all its forms, the air and the sea as well as the land.

Landscapes change faster than buildings and are more clearly subject to seasonal cycles of growth and decay. An architecture that is conceived as analogous to an ever-changing landscape is more temporally aware than other buildings and will require constant re-evaluation, encouraging particularly questioning and creative relations between objects, spaces and users at varied times, scales and dimensions.

\section{The city and the sea}

Architecture's relations with nature and climate have influenced architects since at least Vitruvius in the first century BC. ${ }^{12}$ But the seventeenth and eighteenth centuries instigated a more intense and profound dialogue with nature, establishing an architectural environmentalism that has significantly influenced subsequent centuries. At first this new environmentalism was specific to the garden, but it led to a much wider engagement with the natural world. At Holkham in early eighteenth-century Norfolk, Thomas Coke chose a turbulent coastal setting and commissioned Kent to design a landscape before a house, while the threatening sea was moving inland. The estate's dual orientation established a dialogue between culture - London and the Grand Tour to the south - and the expansive sea to the north. Rather than distinct and sequential, the Enlightenment and romanticism were evolving and interdependent philosophical traditions present throughout the eighteenth century and evident in the landscape garden. One cultivated nature but remained detached, staring south towards the placid Mediterranean and its piercing light. The other did not discard reason but eulogised nature as the means of spiritual self-revelation, travelling north into the stormy sea and overcast sky.

Like the picturesque, the term "romanticism" has often been applied pejoratively, suggesting disengagement and retreat from contemporary concerns. Claiming to heal the rupture of culture from nature, the romantic imagination may instead misrepresent nature, further its commodification, and prevent critical engagement with the natural world. However, in early nineteenth-century London the collaborations and conversations of painters, poets, scientists and architects indicated their mutual respect and overlapping concerns. The search for understanding led the 
intellect as well as emotion, invention as well as history, time as well as place, romanticism was promoted in science as well as art, which were not then opposed in the way they have sometimes subsequently been. Acknowledging the union of nature and culture, romanticism recognised a responsibility to both. The romantic scientist was not external to nature, and neither were the romantic painter and poet.

As romanticism increased the authority of the artist, who more often selected the subject and the site of an artwork, J. M. W. Turner's rising reputation was influential in raising the status of landscape paintings. Depicting a myriad of scenes, whether magnificent or mundane, urban or rural, maritime or industrial, Turner expanded the meanings of the term "landscape". In a nation such as Britain, with a nationally and globally interconnected infrastructure, a clear division between country and city was increasingly untenable and no longer equivalent to nature and culture respectively.

Whether at sea or in the city, Turner painted what he experienced. In London, his deliberately dilapidated studio enabled him to paint in situ. Turner's subject literally entered his work in pigments and pollution. The dirt and rain that landed on unfinished canvases, and Turner incorporated into his paintings, combined with composites of natural and industrial pigments, which he used before any contemporary. ${ }^{13}$ His subject, site and painting practice were perfectly aligned. Rather than a retreat to nature, Turner's romanticism acknowledged the complexity of his time, its climate and weather. Immersed in the hybridised atmospheres and energies that defined early-nineteenth century London, which nature and industry had together created, he offered an early image of anthropogenic climate change.

\section{Factual histories}

Empiricism influenced writing conventions as well as landscape and building design, and informed the relations between them too. Describing actual events and others of his own invention, Giorgio Vasari's Le vite de' piu eccellenti pittori, scultori e architettori (The Lives of the Most Eminent Painters, Sculptors and Architects, 1550), was the first significant history of art and architecture, initiating a new discipline. In the sixteenth century, history's purpose was to offer useful lessons; accuracy was not necessary. In subsequent centuries, empiricism gave greater emphasis to the distinction between fact and fiction, which came to transform historical analysis. Rather than Vasari's focus on individual achievements, historians began to employ a methodical, comparative method to characterise changing cultural, social, political and economic processes in which the deeds of specific protagonists were contextualised. Influenced by the empiricist philosopher Francis Bacon, Giambattista Vico's Scienza nuova (1725), was the first modern history. By the nineteenth century, the art and architectural historian was established as a distinct practitioner and history was naively assumed to a science capable of objective statements, which led to an emphasis on archival research. Science is supported in its claim to objectivity by the presence of its objects of study before the scientist. No archive, however complete, can return the historian to the past and no history is more than an interpretation of the past in the present. Our understanding of the past, which is progressively more distant, is inevitably partial. Laying bare the processes of construction and decay, a history is both a ruin of the past and a speculative reconstruction in the present. ${ }^{14}$ Any history expresses a particular ideology, as does any scientific statement. Selectively focusing on certain information while ignoring others, they cannot be neutral. Whether implicit or explicit, a critique of the present and prospect of the future are evident in both historical and scientific statements.

13 Hackney 1995: 53-54; Townsend 1993 70; Townsend 1995: p. 5.

14 Benjamin 1977:p 177-178. 


\section{Factual fictions}

In valuing direct experience, precise description, and a sceptical approach to "facts", which needed to be repeatedly questioned, the empirical method also created a fruitful climate in which the everyday realism of a new literary genre - the novel - could prosper as "factual fictions". ${ }^{15}$ In contrast to the earlier romance, which incorporated classical mythologies, the novel concentrated on contemporary society and the individualism it professed. The focused investigation and precise description that empiricism demanded was applied to the novel, which emphasised specific times, peoples and places and sought justification through reference to a combination of reasoned explanation and intuitive experience. Recognising a difference in style as well as content, William Congreve remarked that in contrast to "the lofty Language, miraculous Contingencies and impossible Performances" of the romance, novels are "of a more familiar nature' and 'delight us with Accidents and odd Events ... which not being so distant from our Belief bring also the pleasure nearer us". ${ }^{16}$ The uncertainties and dilemmas of identity, as in Locke's assertion that "Socrates waking and sleeping is not the same Person", were ripe for narrative account. ${ }^{17}$ Countering Locke's call for moderation, recognition that we make our own reality was exploited for its creative potential. Notably, Daniel Defoe's Robinson Crusoe (1719), which is often described as the first English novel, is a fictional autobiography, as is his later novel, Moll Flanders (1722).

The early novels - fictional autobiographies - developed in parallel with early diaries - autobiographical fictions. The novel's attention to contemporary individualism was also seen in diary writing, which Locke recommended as a means of personal development. People have written about themselves for millennia but the formation of modern identity is associated with a type of writing that Michel Foucault describes as a "technology of the self". ${ }^{18}$ As Paul de Man remarks: "We assume that life produces the autobiography as an act produces its consequences, but can we not suggest, with equal justice, that the autobiographical project may itself produce and determine the life."19

\section{The life and opinions of John Soane, gentleman}

Emphasising a fascination for landscape and its relationship to dwelling that was to become a principal theme of English literature, Robinson Crusoe even had "my Country-House, and my Sea-Coast-House" on his shipwreck island. ${ }^{20}$ The early English novel's relationship to the picturesque garden has not been acknowledged before, even though they were each a response to empiricism and the secular individualism of eighteenth-century society, and influenced each other. Self-reflection stimulated questions of identity, fractured narratives and digressions in the garden as well as the novel, although the landscape designer emphasised classical mythologies alongside contemporary events. The picturesque garden was both a novel and a romance, conceived according to ut pictura poesis - as with a picture, so also with a poem - a concept that originated in classical antiquity and acquired further resonance due to Locke's concern for the association of ideas as a stimulus to the mind. ${ }^{21}$ Equally, the picturesque garden was equivalent to a history, formulating an interpretation of the past in the present through classical reconstructions, antique sculptures and Mediterranean trees.

The influence of the picturesque garden and novel, as well as Enlightenment architecture, can be seen in the house, museum and office that John Soane created at 12-14 Lincoln's Inn Fields, London. He described Kent as "the father of modern gardening" and an architect of "genius", and was equally indebted to Laurence Sterne's meandering fictional autobiography The Life and Opinions of Tristram 
Shandy, Gentleman (1759-1767) and Nicolas Le Camus de Mézières' claim in 1780 that as architecture follows nature's principles, a house and a garden can be designed in a similar manner and are each equivalent to poetry. Soane conceived 12-14 Lincoln's Inn Fields as a fictional autobiography and picturesque architectural garden, and wrote a novelistic history of his home as a future ruin. ${ }^{22}$

Like a garden, a novel may be emblematic, expressive or a combination of the two. Soane valued architecture that can "please generally and at first sight", while to sustain attention he emphasised that a "building often pleases from its variety and movement whereby the succession of interest is kept up". ${ }^{23} 12-14$ Lincoln's Inn Fields is so excessively emblematic that it is expressive. In conceiving a building as a poem in which emotional and discursive impact is more important than any specific meaning, architects influenced the development of romantic literature. ${ }^{24}$

Hypnerotomachia Poliphili was a further influence: Soane, like Kent, owned several copies. ${ }^{25}$ A building site for over 40 years, Soane conceived his home as a ruin and ruined as much as he built. As he remained on site while the three adjacent buildings were constructed, demolished and rebuilt, 12-14 Lincoln's Inn Fields was then a living ruin unlike the preserved ruin it became after his death in 1837.

Soane enrolled to study architecture at the Royal Academy of Arts in 1771, just three years after its foundation, and became the Professor of Architecture in 1806. The classification of the fine arts in opposition to utility led painters and sculptors to discard the term "design" once it was associated with collective authorship, industrial production and the applied arts. ${ }^{26}$ Among the fine arts, which include the three original visual arts, only in architecture is the term design regularly referred to today. Older and newer meanings of design proliferate in the discourse of architects, often in combination with each other. As in Soane's case, influential architects tend to write and draw a lot as well as build, authoring an interdependent network of drawings, books and buildings that inform each other. Equivalent to a visual and spatial diary, the process of design - from one drawing to the next iteration and from one project to another - is itself a fictional autobiography, a "technology of the self", even when a number of collaborators are involved, formulating a design ethos or "creative myth" for an individual or an office.

\section{Romantic modernism}

For the next hundred years, the picturesque was largely ignored or suppressed within the gothic revival. But in the mid-twentieth century, British modernism was associated with the picturesque and a burgeoning romanticism, encouraging architects to counter an earlier, didactic and universal modernism by embracing history, landscape and environmentalism. Once again, the ruin was adopted as a symbol of hope as well as loss. ${ }^{27}$ Associating the picturesque with liberalism and empiricism, Brenda Colvin emphasised that just 23 out of 60 "native" trees originated in Britain, while Nikolaus Pevsner offered a human equivalent to her sylvan allegory: "England has indeed profited just as much from the un-Englishness of the immigrants as they have profited from the Englishing they underwent". ${ }^{28}$

While eighteenth-century England advocated liberalism, only a small proportion of the population were allowed a university education, the right to vote, and access to a picturesque estate. In contrast, the post-war welfare state aimed to open these rights and pleasures to all classes and the whole population. Commissioned in 1962 to build the new University of East Anglia in late eighteenth-century parkland at Earlham, Norfolk, Denys Lasdun aimed to design "buildings which
22 Le Camus de Mézières 1992: 74; Soane, in Watkin 1996: 491, 608, 642, 647 and 653; Soane 1999: 61-75.

23 Soane, in Watkin 1996: 194.

24 Saisselin 1975: 247-248

25 Gordon 1999: 71-72; Watkin 1996: 246

26 The Abbé Batteux provided the firs detailed categorisation of the fine artsnotably poetry, music, painting, sculpture and architecture-in Les beaux arts reduits à un même principe, 1746 .

27 Colvin 1945: 26-30.

28 Colvin 1972, first edition in 1947; Colvin, 1970: 220, first edition in 1947; Pevsner 1956: 185. 
29 Lasdun 1984:135.

30 Colvin 1970: 34-35, 59, 61; Evelyn 1772: 3 , 28, 34-37; Evelyn 1664: 112-120.

31 Alexander Redhouse and Peter McKinley, "UEA, Denys Lasdun and Partners", lecture, 15 February 1966, quoted in Sanderson 2002: 147.

32 Lasdun 1965: 273

33 Whately $1771153-55,217-2$

34 Denys Lasdun, "UEA Development Plan, December 1962". Lasdun archive, RIBA Library Drawings and Archives Collections, V \& A, London

35 Lasdun, in "Interview with Denys Lasdun”, revised draft, 13 June 1979, p. 11. Lasdun archive, RIBA Library Drawings and Archives Collections, V\&A, London.

36 Gilbert Meason used the term in On the Landscape Architecture of the Great Painter of Italy, 1828, as did John Claudius Loudon in his edited collection of Repton's writings in 1840. Rather than the design of landscapes, Meason and Repton most likely referred to architecture in a landscape setting. responded almost ecologically to unique and specific situations" and persuaded UEA to appoint Colvin as its landscape architect. ${ }^{29}$ She was indebted to John Evelyn's poetic and pragmatic Fumifugium: or The Inconvenience of the Aer and Smoak of London Dissipated (1661), which recognised mitigation and adaptation as responses to anthropogenic climate change three centuries before these principles were widely accepted, and his subsequent book Sylva, or A Discourse of Forest-Trees (1664), which promoted a more sensitive and sustainable modification of nature than before. ${ }^{30}$ Colvin maintained and extended the site's rich variety of natural habitats, and conceived the integration of landscape and architecture in terms of the interdependence of nature and culture, and natural and human biology, associating physical processes with metaphysical dimensions.

Lasdun walked UEA's site "in all seasons, in mist, snow, wind and sun" and travelled Norfolk extensively. ${ }^{31}$ In a key design decision with picturesque connotations, he decided that the various architectural elements "were to be disposed on this site with loving care for the configuration and contours of the landscape, its prospect and aspect". ${ }^{32}$ Holkham was expressive as well as emblematic but later picturesque landscapes, such as Earlham, emphasised sweeping topography rather than iconographic monuments because the expressive garden was then assumed to place fewer restrictions on the imagination. ${ }^{33}$ Expressive rather than emblematic, Lasdun's design exactly inverts the sequence at Holkham, beginning with a tree-lined linear avenue that runs due south until it reaches a 'nodal point' that reveals 'panoramic views' across the university and towards the river. ${ }^{34}$ As at Holkham, the southern orientation refers to Greece and Rome, which at UEA also acknowledges their influence on Lasdun's heroes, Nicholas Hawksmoor, Le Corbusier and John Soane. The north is referred to in terms of climate rather than direction: "As bits get chipped off and bits grow around it, I think it will become part of landscape... On a wet day it may look drab and forbidding, and they might scuttle away from it. On a sunny day it's magical, but then buildings are like that, they should be."35

Exemplifying the emotive power and allegorical potential of architecture and landscape, and the possibility of growth as well as decay, a monumental, living ruin looks to the future as well as the past, generating an appropriate image for a highly regarded and innovative university that is today best known for creative writing and climate change research. But algae and moss, which soon covered the buildings, also turned a past image of the future - a new university - into one of slow decay that was sadly appropriate to the demise of free higher education, one of the emblems of the welfare state.

In the symbiosis of geography and history in an island nation, Lasdun recognised that British architecture is both interdependent with landscape and a form of landscape architecture, an enduring and evolving tradition from the picturesque and romanticism to modernism in which the genius of the place has been made as much as found, the fusion of new ideas, forms and spaces with those already in place, which were themselves sometimes the result of earlier migrations. ${ }^{36}$

\section{Architects of history}

From the Renaissance to the early twentieth century the architect was a historian in the sense that an architectural treatise combined design and history, and a building was expected to manifest the character of the time and knowingly refer to earlier historical eras. Modernism ruptured this system in principle if not always in practice, but it returned with vigour in the mid-twentieth century. 
Architects have used history in different ways, whether to indicate their continuity with the past or departure from it. Even early modernists who denied the relevance of the past relied on histories to justify modernism's historical inevitability and systematic evolution. To some degree, mid-twentieth century architects merely reaffirmed an appreciation of history that was latent in works such as Le Corbusier's Vers une architecture (1923). ${ }^{37}$ But the Second World War was a more scientific war than the First, and nuclear devastation undermined confidence in technological progress, which early modernism had emphasised as a means of social transformation. In the search for stability in the uncertain aftermath of 1945, modernism's previously dismissive reaction to social norms and cultural memories was itself anachronistic. The consequence was not just to acknowledge early modernism's classical heritage but also to place a concern for history at the heart of architecture once again, affirming the liberal humanist tradition that modernism had once seemed to repudiate, and undermining the unnecessary opposition between tradition and innovation that modernism had once seemed to pose.

Critical of international modernism, in 1954 Ernesto N. Rogers promoted appreciation of national and regional architectural cultures. To explain his conception of a building in dialogue with its physical and natural surroundings and contributing to an evolving historical continuity, he quoted from "Tradition and the Individual Talent” (1917), in which T. S. Eliot emphasised that the present alters our understanding of the past as much as the past influences the present. ${ }^{38}$ Admired by Rogers and equally indebted to Eliot's essay, Lasdun noted the value that the poet placed on innovation as well as tradition: "The existing monuments form an ideal order among themselves, which is modified by the introduction of the new (the really new) work of art among them." ${ }^{39}$ Confirming the prevalence of such ideas in postwar architecture, in 1969 Vincent Scully concluded that the architect will "always be dealing with historical problems - with the past and, a function of the past, with the future. So the architect should be regarded as a kind of physical historian ... the architect builds visible history". ${ }^{40}$ As a design is a reinterpretation of the past that is meaningful to the present, transforming both, each building or landscape is a new history. The architect is a historian twice over: as a writer and as a designer.

\section{The creative myth}

Histories and novels each display a concern for the past, present and future. They give meaning to the present and may personify an attitude and an era. The historian acknowledges that the past is not the same as the present, while the novelist inserts the reader in a place and time that feels very present even if it is not. Histories and novels both need to be convincing but in different ways. Although no history is completely objective, to have any validity it must appear truthful to the past. A novel may be believable but not true. But recognising the overlaps between two literary genres, Malcolm Bradbury - co-founder with Angus Wilson of UEA's pioneering creative writing programme - notably described his novel The History Man (1975), as "a total invention with delusory approximations to historical reality, just as is history itself”. ${ }^{41}$

Associating designing with story-telling and history-writing, Lasdun remarked that each architect must devise his or her "own creative myth", which should be "sufficiently objective" and also have "an element of subjectivity; the myth must be partly an expression of the architect's personality and partly of his time, partly a distillation of permanent truths and partly of the ephemerae of the particular moment". ${ }^{42}$ The "creative myth" may be a private inspiration or a public, collective

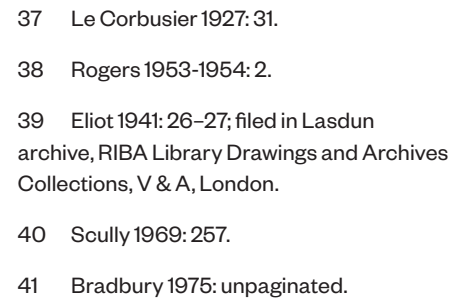
Collections, V \& A, London.

40 Scully 1969: 257.

41 Bradbury 1975: unpaginated. 
narrative that is disseminated widely, either to architects, or to users, or to society as a whole. Emphasising that "I don't mean myth in the sense that it is untrue", Lasdun concluded: "My own myth ... engages with history". 43

As a design is equivalent to a history, we may expect the designer as well as the historian "to have a certain quality of subjectivity" that is "suited to the objectivity proper to history", as Paul Ricouer concludes. ${ }^{44}$ But the designer does not usually construct a history with the rigour expected of a contemporary historian, and we expect the designer to display other qualities of subjectivity as well. Instead, the designer creates novel histories. Equally, a design is equivalent to a novel, convincing the user to suspend disbelief. Part-novelist, part-historian, the architect is the history man. We expect a history or a novel to be written in words, but they can also be cast in concrete or seeded in soil. An architectural book can be a history and a novel, and so can a building or a landscape.

Conceiving a design as both a history and a novel is not exclusive to the analogy of landscape to architecture but it is central to this tradition because of the simultaneous and interdependent emergence of art forms that are usually considered in isolation: the English novel, the analytical and comparative history, the picturesque landscape, and the associated design practice in which ideas are subject to experience and special emphasis is given to natural forces and the environment. Developed in the eighteenth century, this tradition found new emphasis in the mid-twentieth century and continues today, acknowledging innovation as well as continuity. While a prospect of the future is implicit in many histories and some novels, it is explicit in a design, which is always set in the future and imagined before it is built, even if that the future is a nostalgia for the past. The most creative architects have always looked to the past to imagine a future, studying an earlier architecture not to replicate it but to understand and transform it, revealing its relevance to the present and future. Twenty-first century architects need to appreciate the shock of the old as well as the shock of the new. ${ }^{45}$

\section{Coproduction}

From its inception, the weather and climate have been essential to the evolving tradition in which architecture is synonymous with landscape. Despite the burgeoning environmental movement in the 1960s, anthropogenic climate was not widely acknowledged by scientists until the mid-1970s. ${ }^{46}$ In Britain and the many other nations where "romantic modernism" remains an abiding influence and enduring "creative myth", its increasing relevance depends on anthropogenic climate change, which is now the principal means to consider the relations between nature and culture. ${ }^{47}$ Many of the proposed "solutions" to climate change reaffirm a faith in technological progress that has been a principal cause of anthropogenic climate change, and are unlikely to be implemented due to insufficient scientific knowledge and political inertia due to conflicting agendas of countries and corporations. ${ }^{48}$ In a parallel scenario, the rhetoric of sustainability tends to reduce architecture to a technical issue and the architect to a technocrat, employing a debased empiricism devoid of the poetic and practical implications of Evelyn and Colvin's environmental research. ${ }^{49}$ Climate change is not only a scientific concern. The dangers posed by anthropogenic climate change are real and need to be addressed when and where possible. But climate always changes, whether by human agency or other means. In offering a dialogue with the changing environment, recognising the weather as a stimulus to the imagination, and formulating designs that are equivalent to histories and novels, the landscape-architecture tradition is compatible with a complex, creative and contextual engagement with climate 
change that is not only driven by fear and may stimulate cultural, social and environmental benefits, whether at a local, national or regional level.

As an alternative response to anthropogenic climate change, the continuing value of the term "nature" has been questioned recently because nature's separation from culture encourages its exploitation, while encouraging a burgeoning fascination for unfettered nature that allows some sites to be protected and others to be overdeveloped. However, eradicating the term "nature" will aid not hinder its exploitation because commercial, industrial and national interests would be without restraint. As an idea, "nature" is a human construction. But the places, species and phenomena that we include within nature are real and not solely subject to our imagination and will. Just because we've named something does not mean that we have made it, or even understand it, however extensive our influence.

Contemporary technologies - mechanical and digital - influence urban and rural landscapes. For accuracy and efficiency, a modern-day tractor is guided by GPS, a satellite navigation system. At a casual glance, a landscape may appear to be subject to human order, and no more natural than another "cultural" artefact. But it is really teeming with life forms that are subject to their own rhythms and intertwined in a complex network of relations with other life forms, including humanity. The English origin of the term "wilderness" is self-willed land. ${ }^{50}$ According to the entomologist Edward O. Wilson, "insects are the little things that run the world" ${ }^{51}$ Thriving everywhere, they so greatly outnumber humans that their combined weight outweighs the human population by six times, and their history with the plant world is 400 million years older. ${ }^{52}$ Even in a suburban garden there are likely to be around 1500 insect species and a much larger total population. Human decisions influence other life forms but they do not control them. In newly industrialised England, the moth Biston betularia mutated as its habitat was transformed in just a few decades. Renamed Biston carbonaria, its pale wings had turned black, offering camouflage against predators in soot-clad cities.

The term "coproduction" explains nature-culture relations and the cities, landscapes and weathers we inhabit. ${ }^{53}$ Equally, people are natural as well as cultural beings. Just as the intermingling of natural and human forces creates the contemporary weather, a building, garden or field results from the relations between nature and culture that arise during its conception, creation and use. As architecture, landscape and the weather are each a product of nature-culture relations, they inform, affect and alter each other in a complex developmental process that is never one way.

The term "author" has sustained over half a century of criticism because it has been associated with sole authority. But rather than a term such as agency, which may dissipate creativity, the 'coproduction' of multiple authors recognises that natural forces, as well as cultural ones, together create a building or a landscape. Acknowledging that authorship involves accidents as well as intentions, the contemporary sciences of climate change, ecology and complexity theory are consistent with the idea of nature as author. ${ }^{54}$ Sometimes competing, sometimes affirming, each author may inform or deny the other, as in a feisty dialogue of distinct voices and unexpected conclusions in which authorship is temporal and shared, and the immaterial is a coproduction of nature and culture.
50 Dave Foreman, referred to in Merchant 2003: 230.

51 Wilson, quoted in Grissell 2001: 124.

52 Grissell 2001:35, 144, 234

53 Steve Rayner refers to "coproduction" while Carolyn Merchant recognises a "partnership" in which "both humans and nature are active" and nature is not gendered. Herbert Marcuse conceives nature as active, sometimes the "ally" to humanity, sometimes hostile. Rayner 2003: 287; Merchant 2003: 223-231; Marcuse 1972: 65, 69 .

54 Merchant 2003: 230 


\section{References}

Alberti, L. H. (1988). On the Art of Building in Ten Books (J. Rykwert, N. Leach \& R. Tavernor, Trans.). Cambridge, MA., and London, England: MIT Press.

Bate, J. (2000). The Song of the Earth. London, England: Picador.

Benjamin, W. (1977). The Origins of German Tragic Drama (J. Osborne, Trans.). London, England: New Left Books.

Bradbury, M. (1975). Author's Note. In The History Man. London, England: Secker and Warburg. Carson, R. (1987). Silent Spring. Boston, MA.: Houghton Mifflin.

Congreve, W. (1692). Incognita: or, Love and Duty Reconcil'd. A Novel. London, England: Peter Buck.

Colonna, F. (1999). Hypnerotomachia Poliphili: The Strife of Love in a Dream (J. Godwin, Trans.) London, England: Thames and Hudson.

Colvin, B. (1970). Land and Landscape: Evolution, Design and Control. London, England: John Murray.

Colvin, B. (1945). A Planting Plan. In H. Casson, B. Colvin \& J. Groag. Bombed Churches as War Memorials (pp. 26-30). Cheam, England: Architectural Press.

Colvin, B. (1972). Trees for Town and Country, fourth edition. London, England: Lund Humphries. First published in 1947.

Darwin, C. (1996). The Origin of Species. Oxford, England: Oxford University Press.

Davis, L. J. (1996). Factual Fictions: The Origins of the English Novel. Philadelphia, PA: University of Pennsylvania Press.

Defoe, D. (1973). Moll Flanders. New York, NY: Norton.

Defoe, D. (2007). Robinson Crusoe. Oxford, England: Oxford University Press.

De Man, P. (1984). The Rhetoric of Romanticism. New York, NY: Columbia University Press.

Edgerton, D. (2008). The Shock of the Old: Technology and Global History Since 1900. London, England: Profile.

Eliot, T. S. (1941). Tradition and the Individual Talent. In Points of View (pp. 23-34). London, England: Faber and Faber.

Evelyn, J. (1772). Fumifugium: Or, The Inconvenience of the Aer, and Smoake of London Dissipated (S. Pegge, Ed.). London, England: B. White. The 1661 edition has a slightly different title.

Evelyn, J. (1664). Sy/va, or A Discourse of Forest-Trees, and the Propagation of Timber in His Majesties Dominions. London, England: Royal Society.

Foucault, M. (1984). On the Genealogy of Ethics: An Overview of Work in Progress. In The Foucault Reader (pp. 340-372) (P. Rabinow, Ed.). London, England: Random House.

Foucault, M. (1988). Technologies of the Self. In L. H. Martin, H. Gutman,, \& P. H. Hutton (Eds). Technologies of the Self: A Seminar with Michel Foucault (pp. 16-49). London, England: Tavistock. Glover, L. (2006). Postmodern Climate Change. London, England, and New York, NY: Routledge.

Gordon, S. (1999). The lconography and Mythology of the Eighteenth-Century English Landscape Garden. PhD thesis, University of Bristol, England.

Grissell, E. (2001). Insects and Gardens: In Pursuit of Garden Ecology. Portland, OR: Timber Press. Hackney, S. (1995). The Condition of Turner's Oil Paintings. In J. Townsend (Ed.), Turner's Painting Techniques In Context (pp. 50-54). London, England: UKIC.

Hart, V., \& P. Hicks. (2006). Palladio's Rome: A Translation of Andrea Palladio's Two Guidebooks to Rome. New Haven, $\mathrm{CT}$, and London, England: Yale University Press.

Hulme, M. (2009). Why We Disagree About Climate Change. Cambridge, England: Cambridge University Press.

Jenner, M. (1995). The Politics of London Air: John Evelyn's Fumifugium and the Restoration. The Historical Journal, vol. 38, no. 3, pp. 535-551. 
Lasdun, D. (1984). "The Architecture of Urban Landscape". In D. Lasdun (Ed.) Architecture in an Age of Scepticism: A Practitioner's Anthology Compiled by Denys Lasdun (pp. 134-159). London, England: Heinemann.

Lasdun, D. (1965). His Approach to Architecture. Architectural Design, vol. 35 (June), pp. 271-291. Le Camus de Mézières, N. (1992). The Genius of Architecture; or, the Analogy of That Art With Our Sensations (D. Britt, Trans.). Santa Monica, CA: The Getty Center.

Le Corbusier. (1927). Towards a New Architecture (F. Etchells, Ed.). London, England: Rodker.

Locke, J. (1975), An Essay Concerning Human Understanding (P. H. Nidditch, Ed.). Oxford,

England: Clarendon Press.

Marcuse, H. (1972). Counterrevolution and Revolt. Boston, MA: Beacon Press.

Merchant, C. (2003). Reinventing Eden: The Fate of Nature in Western Culture. New York, NY, and London, England: Routledge.

Norberg-Schulz, C. (1996). Nightlands: Nordic Building. Cambridge, MA, and London, England: MIT Press.

Palladio, A. (1965). The Four Books of Architecture (I. Ware, 1738, Trans.). New York, NY: Dover. Pevsner, N. (1956). The Englishness of English Art. London, England: Architectural Press.

Plato. (1929). Timaeus, Critias, Cleitophon, Menexenus, Epistles (R. G. Bury, Trans.) Cambridge, MA: Harvard University Press.

Rayner, S. (2003). Domesticating Nature: Commentary on the Anthropological Study of Weather and Climate Discourse. In S. Strauss \& B. Orlove (Eds), Weather, Climate, Culture (pp. 277-290).

Oxford, England, and New York, NY: Berg.

Repton, H. (1969). The Landscape Gardening and the Landscape Architecture of the Late Humphry Repton, Esq. (J. C. Loudon Ed.). Farnborough, England: Gregg International.

Ricoeur, R. (1965). Objectivity and Subjectivity in History. In History and Truth (pp. 21-40) (C. A. Kelbley, Trans.). Evanston, IL: Northwestern University Press.

Rogers, E. N. (1953-1954). Continuità. Casabella Continuità (December-January).

Saisselin, R. (1975). Architecture and Language: The Sensationalism of Le Camus de Mézières. The British Journal of Aesthetics, 15, no. 3, (Summer), pp. 239-253.

Sanderson, M. (2002). The History of the University of East Anglia Norwich. London, England: Hambledon and London.

Scully, V. (1969). American Architecture and Urbanism. London, England: Thames and Hudson.

Shaftesbury, A. A. Cooper, third Earl of. (1999). Characteristicks of Men, Manner, Opinions, Times (P. Ayres, Ed.). Oxford, England: Clarendon Press.

Shaftesbury, A. A. Cooper, third Earl of. (1900). The Life, Unpublished Letters, and Philosophical Regimen of Anthony, Earl of Shaftesbury (B. Rand, Ed.). London, England: Swan Sonnenschein.

Simmel, G. (1965). The Ruin. In Essays on Sociology, Philosophy and Aesthetics (pp. 259-266).

New York, NY: Harper and Row.

Soane, J. (1999). Crude Hints towards an History of my House in L(incoln's) I(nn) Fields, 1812. In C. Woodward (Ed.), Vision of Ruin: Architectural Fantasies and Designs for Garden Follies (pp. 61-75). London, England: Sir John Soane's Museum.

Sterne, L. (2003). The Life and Opinions of Tristram Shandy, Gentleman (M. New \& J. New, Eds). London, England: Penguin.

Townsend, J. (1993). Turner's Painting Techniques. London, England: Tate Publishing.

Townsend, J. (1995). Turner's Use of Materials, and Implications for Conservation. In J. Townsend (Ed.), Turner's Painting Techniques In Context (pp. 5-11). London, England: UKIC.

Tuveson, E. (1960). The Imagination as a Means of Grace: Locke and the Aesthetics of Romanticism. Berkeley and Los Angeles, CA: University of California Press.

Vasari, G. (1960). Vasari on Technique, 2nd edition, 1568 (L. S. Maclehose, Trans.). New York, NY: Dover.

Vico, G. (1999). New Science (D. Marsh, Trans.). London, England and New York, NY: Penguin Books.

Vitruvius. (1960). The Ten Books on Architecture (M. H. Morgan, Trans.). New York, NY: Dover. Watkin, D. (1996). Sir John Soane: Enlightenment Thought and the Royal Academy Lectures. Cambridge, England: Cambridge University Press.

Whately, T. (1771). Observations on Modern Gardening, Illustrated by Descriptions. London, England: T. Payne. 